J. Product. \& Dev., 24(4): 787-805(2019)

\title{
ENHANCING QUALITY ATTRIBUTES OF GUAVA FRUITS DURING COLD STORAGE BY USING EDIBLE COMPOSITE COATING (CHITOSAN) AND CALCIUM NITRATE
}

\author{
Ahmed M.S. Abd El-Rahman*; Osama A.I. Zagzog*; Nermeen I. El- \\ Naggar* and **Mohamed M.M. Gad \\ *Plant Prod.Dept. (Pomology), Fac. Tec. \&Dev., Zagazig Univ., Egypt \\ **Hort. Dept. (Pomology), Fac. Agric., Zagazig Univ., Egypt \\ zagzog_1000@yahoo.com, nielnagar@hotmail.com
}

\section{ABSTRACT}

The current investigation was carried out during 2015 and 2016 seasons on El-mamoura guava fruits (Psidium guajava L.) to study the effect of calcium nitrate and chitosan coating treatments on the physico-chemical characteristics of the fruits during cold storage period. All treatments prevented fruit decay compared with control which lost $26.14 \%$ (average of the two seasons) of its fruits.

Guava fruits didn't lost any weight during the first two weeks of cold storage in both seasons and after 43 days the least weight loss percentages were for the treatments of Calc. Nit. 4\% + Chitosan 0.5\% in the first season and Calc. Nit. $2 \%+$ Chitosan $1 \%$ in the second season. The above treatment of Calc. Nit. $2 \%+$ Chitosan $1 \%$ had the highest significant average of V.C and gave the highest firmness values in both seasons and its fruits had the highest citric acid content in the last interval of the first season. All treatments maintained the TSS content in guava fruits during cold storage period and the treatment of Calc. Nit. $4 \%+$ Chitosan $0.5 \%$ had the highest significant average value in both seasons.

Conclusively, it is recommending treatment with $0.5 \%$ chitosan as a coating and calcium nitrate $5 \%$ to guava fruit cv. ELmamoura to improving fruit quality for cold storage a long time.

Key words: Enhancing Quality, Guava Fruits, Cold Storage, Edible Composite Coating, Chitosan, Calcium Nitrate 


\section{INTRODUCTION}

Guava (Psidium guajava L.) is a tropical fruit, widely consumed fresh and processed. It is a good source of V.C where it contains almost five times as much as V.C as oranges (Ashaye et al., 2005). Guava showed high content of dietary fiber $(48.55 \%$ in pulp $-49.42 \%$ in peel) and extractable polyphenols $(2.62 \%$ in pulp $-7.79 \%$ in peel) which is correlated with a remarkable antioxidant activity (Escrig et al., 2001). Guava fruits are very perishable, delicate to handle and starts to deteriorate quickly during storage or marketing. Guava fruits are harvested then subject to ripening, senescence, microbial and pests' infestation, water loss, anatomical, morphological and compositional changes. Therefore, the development of adequate fruit postharvest treatments is of great necessity and economic importance.

Since 1962, calcium treatments were used to improve fruit storage life, whereas, calcium appears to have an important complementary regulating role to optimum storage temperature in metabolism of fresh fruits. Calcium are exhibited a distinct role in sustaining cell wall integrity by interrelating with pectic acid of the cell wall to form calcium pectate which facilitate cross linkage of pectic compounds of the cell wall. $\mathrm{Ca}$ is being used as a firming agent and preservative in the fruit industry for fresh-cut and whole produces. Ca pretreatments of loquat fruit exhibited increased shelf life and firmness as compared with untreated fruits (Akhtar et al., 2010). Firmness of peach fruits was increased by dipping in $\mathrm{CaCl}_{2}$ solution (Manganaris et al., 2007). Manganaris et al. (2005) also reported that fruits treated with calcium salts showed higher firmness (34.2-44.7\%) as compared with the non-treated fruits.

Among edible coatings, chitosan, which has a chemical structure close to that of cellulose, has long been storage known to protect perishable produce from deterioration by reducing transpiration, respiration and maintaining the textural quality. Chitosan (poly $\beta-(1-4) \mathrm{N}$-acetyl-dglucosamine), a deacetylated form of chitin, is a natural compound obtained from crustacean shells (Tan et al., 1996). Chitosan has been successfully tried and recommended for enhancing the shelf life of several fruits such as litchi (De Reuck et al., 2009), mango (Chien et al., 2007), peaches, Japanese pears, and kiwifruit (Du et al., 1997) and guava (Fekry ,2018). 
The aim of the present study was to study the effect of calcium nitrate and chitosan coating treatments on El-Mamoura guava fruits during cold storage period.

\section{MATERIALS AND METHODS}

This study was carried out during 2015 and 2016 seasons on El-mamoura guava fruits (Psidium guajava L.). The fruits were harvested from a private orchard (the trees were 10-year-old, grown in sandy soil at $5 \times 5$ meters apart and received the standard horticultural practices adopted in this area) at El-Tahrer north district, El-Bihira Governorate, Egypt. Fruits at mature-green or breaker stage were picked on the same date in mid-September in both seasons, using small clippers, packed in carton boxes, then transported directly to Post-Harvest Laboratory in Horticulture Department, Faculty of Agriculture, Zagazig University, Egypt. Chosen fruits sorted to be healthy, free of physiological and pathological disorders and uniform in color and size. Finally, it was washed using tap water then air-dried before treatment.

The experimental design was factorial ( 9 treatments $\times 5$ weeks $)$ in a complete randomized design, in three replicates, each replicate contained 60 uniform fruits. All fruits packed in perforated (0.06\% of area) 20 -micron thickness low-density polyethylene (LDPE) bags after immersing the fruits in the following liquids for two minutes coating treatments.

1. $\mathrm{Ca}\left(\mathrm{NO}_{3}\right)_{2}$ of $0 \%$ +chitosan of $0 \%$.

2. $\mathrm{Ca}\left(\mathrm{NO}_{3}\right)_{2}$ of $0 \%+$ chitosan of $0.5 \%$.

3. $\mathrm{Ca}\left(\mathrm{NO}_{3}\right)_{2}$ of $0 \%$ + chitosan of $1 \%$.

4. $\mathrm{Ca}\left(\mathrm{NO}_{3}\right)_{2}$ of $2 \%$ +chitosan of $0 \%$.

5. $\mathrm{Ca}\left(\mathrm{NO}_{3}\right)_{2}$ of $2 \%+$ chitosan of $0.5 \%$.

6. $\mathrm{Ca}\left(\mathrm{NO}_{3}\right)_{2}$ of $2 \%$ +chitosan of $1 \%$.

7. $\mathrm{Ca}\left(\mathrm{NO}_{3}\right)_{2}$ of $4 \%$ + chitosan of $0 \%$.

8. $\mathrm{Ca}\left(\mathrm{NO}_{3}\right)_{2}$ of $4 \%+$ chitosan of $0.5 \%$.

9. $\mathrm{Ca}\left(\mathrm{NO}_{3}\right)_{2}$ of $4 \%$ +chitosan of $1 \%$.

The fruits were stored for $2,3,4,5$ and 6 weeks at $8 \pm 1^{\circ} \mathrm{C}$ (RH 85-90\%). Evaluation of the tested treatments, cold storage period and their interaction on guava fruits were carried out through the following quality attributes:

Fresh weight losses percentage (FWL\%): The fruits weighed before cold storage to obtain the initial weight. Then, it weighed after each period of cold 
storage. FWL calculated as a percentage of the initial weight according to the following equation:

$$
F W L \%=\frac{W i-W s}{W i} \times 100
$$

Where, Wi = Initial fruit weight, Ws = Fruit weight at each sampling period (Hazali et al., 2013; Ibrahim and Gad, 2015).

Fruit decay percentage (FD \%): It was determined as percentage of decayed fruits.

Fruit pulp firmness (FPF): It was determined on five fruits per replicate on two opposite sides of the equatorial region of the fruit after peel removal by using a Push Pull dynamometer (Model FD 101). The values expressed as $\left(\mathrm{g} / \mathrm{cm}^{2}\right)$ (Ibrahim and Gad, 2015).

Juice total soluble solids content (TSS \%): It was determined using a hand refractometer as Brix $^{\circ}$ (Hazali et al., 2013).

Ascorbic acid (vitamin C) content: It was determined by titration in presence of 2,6 dichlorophenol-indophenol dye as indicator against $2 \%$ oxalic acid solution as substrate. Ascorbic acid calculated as milligrams per $100 \mathrm{ml}$ of juice (Kabasakalis et al., 2000).

Juice titratable acidity: It was determined by titrating an aliquot of juice against $0.1 N \mathrm{NaOH}$ in presence of phenolphthalein dye as indicator, the results calculated as grams of citric acid per $100 \mathrm{ml}$ fruit juice (AOAC, 1995). All chemicals used in this work obtained from El-Gomhouria for Trading Chemicals and Medical Appliances, El-Sawah, El-Amiria, Cairo, Egypt.

\section{Statistical analysis}

Statistical analysis conducted for the collected data according to Snedecor and Cochran (1989). Data subjected to the ANOVA and a factorial in a complete randomized design was used (Steel and Torrie, 1980). Means tested using Duncan's test at 5\% to investigate the significant differences between coating treatments, weeks of storage and their interaction.

\section{RESULTS AND DESCUSSION}

\section{Fresh weight losses (FWL) percentage:}

Guava fruits didn't lost any weight during the first two weeks of cold storage in both seasons (Table 1). By the progress of days some treatments didn't loss weigh till the fourth week (Calc. Nit. 2\% + Chitosan 1\%and Calc. Nit. $4 \%$ + Chitosan $0 \%$ in the first season and Calc. Nit. $0 \%$ + Chitosan $0.5 \%$ 
and Calc. Nit. $2 \%+$ Chitosan $1 \%$ in the second season). By the end of the storage period ( 6 week) the least weight loss percentages were for the treatments of Calc. Nit. $4 \%+$ Chitosan $0.5 \%$ in the first season and Calc. Nit. $2 \%+$ Chitosan $1 \%$ in the second season.

Calcium plays an effective role in membrane functionality and integrity maintenance by binding to the polar head group of the phospholipids. Hence the lower loss of phospholipids with reduced ion leakage could be responsible for the lower weight loss in the treated fruits (Lester and Grusak, 1999). Probably, due to delaying enzymatic activities responsible for senescence and moisture loss (Jouki, and Khazaei,, 2012).

Chitosan forms a layer of semi-transparent to smooth the pericarp surface (González-Aguilar et al.,2009) and can be used as a protective barrier to not only hinder transpiration process resulting in low fruit weight loss, but also hinder $\mathrm{O}_{2}$ consumption resulting in decreasing respiration rate and ethylene production, and then increasing fruit shelf-life (Trung et al., 2011).

\section{Fruit decay percentage (FD \%):}

The data in Table 2 showed that all treatments prevented fruit decay during the 43 days of cold storage (except a percentage less than $1 \%$ for Calc. Nit. $0 \%+$ Chitosan $0.5 \%$ treatment) compared with control which lost $26.14 \%$ (average of the two seasons) of its fruits.

Chitosan has a double mechanism of action. The first is restraining the propagation of harmful germs by inhibiting the spore germination, germ tube elongation and mycelial growth of the decay- causing fungi and the second is the induction of defense responses in host tissues and promoting protection from further fungal by chitinase, a defense enzyme, which catalyzes the hydrolysis of Chitin, a common component of fungal cell walls, thus effectively controlled fruit decay (Zhang et al., 2011). Moreover, chitosan treatment showed positive effects in maintaining membrane integrity and increasing the activities of antioxidant enzymes and phenolic compounds (Hong et al., 2012 and Kumari et al., 2015). Anti-decay effects of chitosan edible coating were observed on table grapes (Xu et al., 2007), strawberry (Kazemini, 2012) and jujube fruit (Wang et al., 2014).

The incorporation of calcium ions in fruit tissue promotes new cross-links between anionic homogalacturonans, strengthening the cell wall and particularly the middle lamella which is responsible for holding cells together.

Thus, increasing the stability of the cell wall and middle lamella by 
calcium treatment which can be expected to improve fruit resistance to enzymes caused by fungal pathogens (Hernandez-Munoz et al., 2008). These results are in line with those obtained by Fatma-Shaaban (2006); ElBadawy (2007) and Hernandez-Munoz et al., (2008).

\section{Fruit pulp firmness (FPF):}

The data in Table 3 showed that the best results were obtained by the treatment of Calc. Nit. $4 \%+$ Chitosan $0.5 \%$ in the first 15 days in the first season and after 22 and 29 days in the second season. By the end of the storage period the treatment of Calc. Nit. $2 \%$ + Chitosan $1 \%$ gave the highest firmness values in both seasons.

Fruit softening occurs due to deterioration in the cell structure, the cell wall composition and the intracellular materials (Vogler et al., 2015; Romanazzi et al., 2016). The maintenance of fruit firmness by chitosan treatments could be due to their higher antifungal activity and covering of the cuticle and lenticels, thereby reducing infection, respiration and other ripening processes during storage (Ali et al., 2005). Also, the treatment of chitosan is suppresses the activity of degradable cell-structured enzyme, so that it may give better contribution during fruit storage (Li et al. 2006) and maintain fruit firmness (Hanani et al., 2012). In addition, chitosan cause a reduction in cell wall degradation, which in turn maintained cell turgidity and the protected structure of cell wall (Bal, 2013).

Calcium has a vital role in maintaining and modulating various cell functions by increasing membrane stability, cell wall strength and maintaining the cell to cell contact resulted in reducing degradation of middle lamella (Martin-Diana et al., 2007 and Dodd et al., 2010). This is due to a decrease in the activity of 1-aminocyclopropane-1-carboxylic acid oxidase (Guan et al., 1991).

\section{Juice titratable acidity:}

All treatments had an effect of maintaining the citric acid content in guava fruits during cold storage period (Table 4) and the best results were for the treatments of Calc. Nit. $2 \%+$ Chitosan $1 \%$ in the first season and Calc. Nit. $0 \%+$ Chitosan $1 \%$ in the second season where the fruits had the highest citric acid content in the last interval.

Gradually decrease in acidity during storage at low temperature and might be due to the conversion of acids into sugars and rapid utilization of 
organic acids in the respiratory process (Chulaki et al., 2017 and Nandaniya et al., 2017). The higher acidity in fruits treated with chitosan could be attributed to reduction in respiration rates and metabolic activities, thereby preventing loss of organic acids during cold storage (Hernandez-Munoz et al., 2008).Similar results with chitosan have been reported in plum (Bal, 2013), pomegranate (Zahran et al., 2015) and guava (Chawla et al., 2018).

Calcium is found almost equally effective in maintaining higher acidity during low temperature storage. The higher acidity in fruits treated with calcium might be due to decreased hydrolysis of organic acids and subsequent accumulation of these acids, which are oxidized at a slower rate because of decreased respiration (Gupta et al., 2011).

\section{Ascorbic acid (vitamin C)}

Table 5 explained that most treatments had high V.C content and its loss was slowed than control during the storage period. The treatment of Calc. Nit. $2 \%$ + Chitosan $1 \%$ had the highest significant average of V.C.

Coatings serve as a protective layer and control the permeability of $\mathrm{O}_{2}$ and $\mathrm{CO}_{2}$, thus decreasing the autoxidation of ascorbic acid (Abd El-Moneim et al., 2015).The higher level of ascorbic acid in chitosan-coated fruit might reflect the low oxygen permeability, slowing down the respiration rate, which reduced the activity of the enzymes involved in the oxidation of ascorbic acid and delays the deteriorative oxidation reaction of ascorbic acid of fruit (Bal, 2013). Similarly, post-harvest application of calcium during storage was better in the retention of ascorbic acid compared to control, might be attributed to the slow rate of oxidation in the respiration process that delays the overall ripening and senescence (Deepthi et al., 2016).

\section{Juice total soluble solids content (TSS \%):}

All treatments maintained the TSS content in guava fruits during cold storage period (Table 6) and the best results were for the treatment of Calc. Nit. $4 \%$ + Chitosan $0.5 \%$ where it had the highest significant average value in both seasons. The total soluble solids (TSS) of the fruits increased with increase in storage period. That data agree with those of Rama and Sudhakar (2014) on guava where they reported that TSS at full ripe stage was high in $1 \%$ chitosan treated fruits which might be due to lower rate of respiration coupled with reduced metabolism. 
The increase in fruit TSS with advancement of storage period can be related to several factors as, increase enzymes activity responsible for starch hydrolysis into sugars (Chawla et al., 2018), hydrolysis of cell wall polysaccharides and hemicelluloses (Hernandez-Munoz et al., 2008 and Comabella \& Lara, 2013), conversion of acids to sugars (Deepthi et al., 2016 and Chulaki et al., 2017) and increased percentage of dry matter due to water loss in the fruit (Nandaniya et al., 2017).

Conclusively, it is recommending treatment with $0.5 \%$ chitosan as a coating and calcium nitrate $5 \%$ to guava fruit cv. ELmamoura to improving fruit quality for cold storage a long time.

\section{REFERENCES}

Abd El-Moneim, E.A.A., H.M. Kamel, Z.A. Zaki and M.E. Abo Rehab (2015). Effect of Honey andCitric Acid Treatments on Postharvest Quality of Fruits and Fresh-Cut of Guava. World Journal of Agricultural Sciences, 11(5): 255-267.

Akhtar, A., Abbasi, N. A., \& Hussain, A. (2010). Effect of calcium chloride treatments on quality characteristics of loquat fruit during storage. Pakistan Journal of Botany, 42, 181-188.

Ali, A., M.T.M. Muhammad, K. Sijam and Z.A.R. Mohamad (2005). Effect of chitosan coating on the retention of colour development and firmness of papaya fruit during storage. In: Proceedings of First International Symposium on Papaya, 22-24 November, Genting Highlands, Malaysia.

AOAC (1995). Official Methods of Analysis of (AOAC) International, $6^{\text {th }}$ Ed., Vol II, Association of Official Agricultural Chemists, Gaithersburg, MD.

Ashaye, O.A.; S.O. Babalola; A.O. Babalola; J.O. Aina and S.B. Fasoyiro (2005). Chemical and organoleptic characterization of pawpaw and guava leathers. World J. Agr. Sci., 1(1):50-51.

Bal, E. (2013). Postharvest application of chitosan and low temperature storage affect respiration rate and quality of plum Fruits. Journal of Agricultural Science and Technology, 15: 1219-1230. 
Chawla, S., R. Devi and V. Jain (2018). Changes in physicochemical characteristics of guava fruits due to chitosan and calcium chloride treatments during storage. Journal of Pharmacognosy and Phytochemistry, 7(3): 1035-1044.

Chien PJ, Sheu F, Yang FH. (2007). Effects of edible chitosan coating on quality and shelf-life of sliced mango fruit. J. Food Eng., 2007; 78:225-29.

Chulaki, M.M.; Pawar, C.D.; Khan, S.M. and Khan, A.M.( 2017). Effects of ascorbic acid and calcium chloride on chemical properties of firm flesh jackfruit bulbs. Journal of Pharmacognosy and Phytochemistry, 6(5): 654658.

Comabella, E., and I. Lara (2013). Cell wall disassembly and post-harvest deterioration of 'Sweetheart' sweet cherry fruit: Involvement of enzymic and non-enzymic factors. Pure and Applied Chemical Sciences, 1, 1-18.

De Reuck K, Sivakumar D, Korsten L.(2009). Effect of integrated application of chitosan coating and modified atmosphere packaging on overall quality retention in litchi cultivars. J Sci Food Agric. 2009; 89:915-20.

Deepthi, V.P., R.C. Sekhar, D. Srihari and A.S. Sankar(2016). Guava fruit quality and storability as influenced by harvest maturity and postharvest application of calcium salts. Plant Archives, 16 (1): 174-182.

Dodd, A.N., Kudla, J. and Sanders, D. (2010). The language of calcium signaling. Annu. Rev. Plant Biol., 61, 41-42.205-209.

Du J, Gemma H, Iwahori S.(1997). Effects of chitosan coating on the storage of Peach, Japanese pear and Kiwifruit. J Jpn Soc Hort Sci., 66:15-22.

El-Badawy, H.E.M. (2007). Trials to improve marketing characteristics and prolonging storage life of persimmon and mango fruits. Ph.D. Thesis, Fac. Of Agric., Benha Univ., Egypt.

Escrig, A.J.; M. Rincón; R. Pulido and F.S. Calixto (2001). Guava fruit (Psidium guajava L.) as a new source of antioxidant dietary fiber. J. Agric. Food Chem., 49 (11): 5489-5493.

Fatma-Shaaban, K.M. (2006). Effect of some pre and postharvest treatments on storability of guava fruits. M.Sc. Thesis, Fruit Science, Fac. of Agric., Ain Shams Univ., Egypt.

Fekry, O. M. (2018). Effect of edible coating chitosan and calcium gluconate on maintaining fruit quality and marketability of Guava (Psidium guajava) fruits during storage. Middle East Journal of Applied Sciences.Vol. 8 (4): 1046-1060. 
Gonzalez-Aguilar, G.A., E. Valenzuela-Soto, J. Lizardi-Mendoza, F. Goycoolea, M.A. MartinezTellez and M.A. Villegas-Ochoa (2009). Effect of chitosan coating in preventing deterioration and preserving the quality of fresh-cut papaya. Maradol J. Sci. Food Agric., 89:15-23.

Guan, J.F., Shu, H.R. and Huang, T.D. (1991). The effect of calcium on ethylene production in 'Starkinson' apple. Acta Horticulturae Sinica, 18, 205-209.

Gupta, N., S.K. Jawandha, and P.S. Gill (2011). Effect of calcium on cold storage and post-storage quality of peach. Journal of Food Science and Technology. 2011, 48:225-229.

Hanani, N.M.Z., H.M.S. Zahrah and A.H. Zaibunnisa (2012). Effect of chitosanpalm stearin edible coating on the post-harvest life of star fruits (Averrhoa carambola L.) stored at room temperature. Intl Food Res J., 19 (4): 1433-1438.

Hazali, N., A.R.A. Tajudin, N.M. Nor, M. Ibrahim and M.N.A. Yahya (2013). Physicochemical Characteristics of Belimbing Dayak (Baccaurea angulata) Juice Beverages. European Inter. J. of Sci. and Tech., 2: 203210.

Hernandez-Munoz, P., E. Almenar, V. Del Valle, D. Velez and R. Gavara (2008). Effect of chitosan coating combined with post-harvest calcium treatment on strawberry (Fragaria $\mathrm{x}$ ananassa) quality during refrigerated storage. Food Chemistry, 110:428-435.

Hong, K., J. Xie, L. Zhang, D. Sun and D. Gong (2012). Effects of chitosan coating on postharvest life and quality of guava (Psidium guajava L.) fruit during cold storage. Scientia Horticulturae,144:172-178.

Ibrahim, M.M. and Gad, M.M. (2015). The Relationship between Harvest Date and Storage Life of Washington Navel Orange Fruits. Middle East J. Appl. Sci. 5(4): 1247-1256.

Jouki, M. and N. Khazaei (2012). "The Effect of Modified Atmosphere Packaging and Calcium Chloride Dipping on the Quality and Shelf Life of Kurdistan Strawberries.” J. Food Process Tech., 3 (10): 1-7.

Kabasakalis, V., Siopidou, D., and Moshatou, E. (2000). Ascorbic acid content of commercial fruit juices and its rate of loss upon storage. Food chemistry, 70(3), 325-328. 
Kazemeini, S.E. (2012). Effect of chitosan and starch edible coating and hot water treatment on postharvest life and quality of strawberry. M.S. Thesis in Horticultural Science. Shiraz University, 73 p.

Kumari, P., K. Barmana, V.B. Patel, M.W. Siddiqui and B. Kolec (2015). Reducing postharvest pericarp browning and preserving health promoting compounds of litchi fruit by combination treatment of salicylic acid and chitosan. Scientia Horticulture, 197, 555-563.

Lester, G.E. and M.A. Grusak (1999). Post-harvest application of Calcium and Magnesium to honeydew and netted muskmelons: Effects on tissue ion concentrations, quality and senescence. Journal of the American Society for Horticultural Science, 124:545-552.

Li, R., P. Guo, M. Baum, S. Grando and S. Ceccarelli (2006). Evaluation of chlorophyll content and fluorescence parameters as indicators of drought tolerance in barley. Agric Sci. China, 5 (10): 751-757.

Manganaris, G. A., Vasilakakis, M., Diamantidis, G., \& Mignani, I. (2005). Effect of calcium additives on physic chemical aspects of cell wall pectin and sensory attributes of canned peach. Journal of the Science of Food and Agriculture, 85(10), 1773-1778.

Manganaris, G. A., Vasilakakis, M., Diamantidis, G., \& Mignani, I. (2007). Effect of postharvest calcium application on the tissue calcium, quality attributes, incidence of flesh browning and cell wall physicochemical aspects of peach fruits. Food Chemistry, 100(4), 1385-1392.

Martin-Diana, A.B., Rico, D., Frias, J.M., Barat, J.M., Henehan, G.T.M. and Barry-Ryan, C. (2007). Calcium for extending the shelf life of fresh whole and minimally processed fruits and vegetables: a review. Trends Food Sci. Technol., 18, 210-218

Nandaniya, U.L., D.K. Gojiya, R.D. Bandhiya, D.K. Antala and P.G. Scholar (2017). Effect of Pre-Treatments on Biochemical and Microbial Parameters of Guava Fruit during storage. Int. J. Nutr. Sci. \& Food Tech., 3:3, 37- 42 .

Romanazzi G, Sanzani SM, Bi Y, Tian S, Martínez PG, Alkan N.(2016). Induced resistance to control postharvest decay of fruit and vegetables. Postharvest Biology and Technology, 122:82-94.

Snedecor, G.W. and W.G. Cochran (1989). Statistical Methods, 8thEdn. Ames: Iowa State Univ. Press Iowa. 
Steel, R.G. and J.H. Torrie (1980). Principles And Procedures Of Statistics. Me-Graw Hill Book Co. Inc., NY, USA, 633.

Tan SC, Tan TK, Wong SM, Khor E. (1996). The chitosan yield of zygomycetes at their optimum harvesting time. Carbohydr. Polym.; 30:239-42.

Trung, T.S., N.T.H. Phuong and W.F. Stevens (2011). Protective effect of chitosan and polyethylene film wrapping on postharvest storange of sugar apples. Asian J. Food Agro-Industr, 4 (2): 81- 90.

Vogler H, Felekis D, Nelson BJ, Grossniklaus U.(2015). Measuring the mechanical properties of plant cell walls. Plants., 4:167-182.

Wang, L., H. Wu, G. Qin and X. Meng (2014). Chitosan disrupts Penicillium expansum and controls postharvest blue mold of jujube fruit. Food Control, 41, 56-62.

Xu, C., B. Zhao, Y. Ou, X. Wang, X. Yuan and Y. Wang (2007). Elicitor enhanced syringing production in suspension cultures of Saussurea medusa. World J. Microbiol Biotechnol, 23: 965-970.

Zahran, A.A.H., R.A. Hassanein and A.T. AbdelWahab (2015). Effect of chitosan on biochemical composition and antioxidant activity of minimally processed 'Wonderful' pomegranate arils during cold storage. Journal of Applied Botany and Food Quality, 88:241-248.

Zhang, H., R. Li, and W. Liu (2011). Effects of chitin and its derivative chitosan on postharvest decay of fruits: A review. Intl. J. Mol. Sci., 12 (2): 917-934. 


\section{تحسين خصائص الجودة لثمار الجوافة اثثاء التخزين المبرد باستخدام

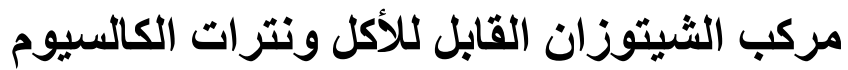

*|حمد محمد السيد عبدالرحمن - * أسامه أحمد أبراهيم زقزوق - نرمين إسماعيل النجار - **محمد ممتاز محمد جاد الزاد

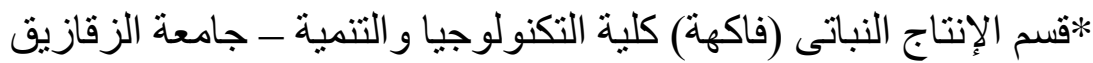



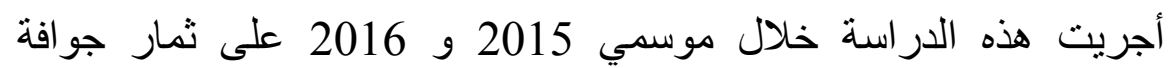

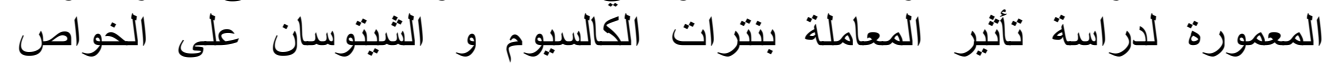

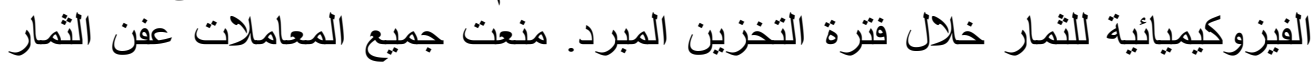

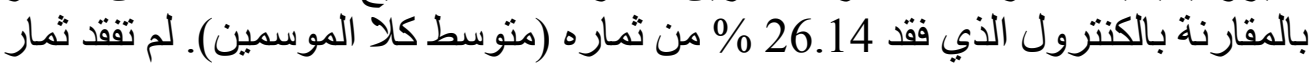

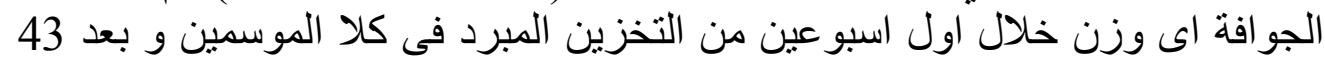

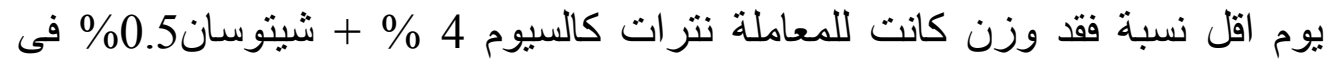

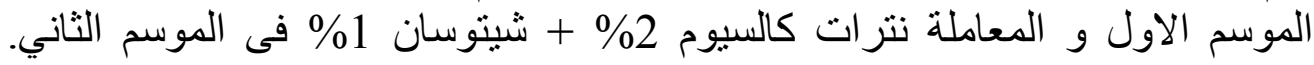

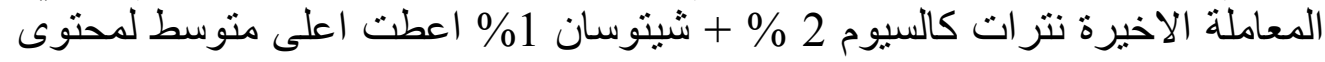

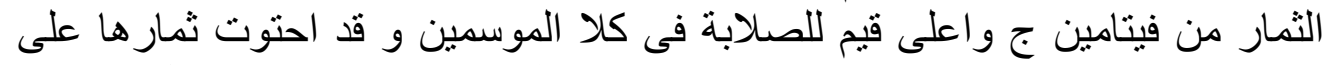

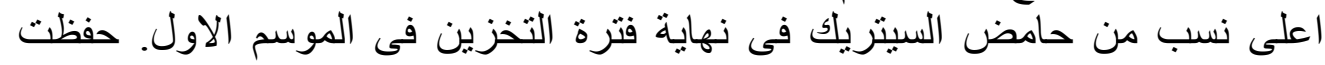

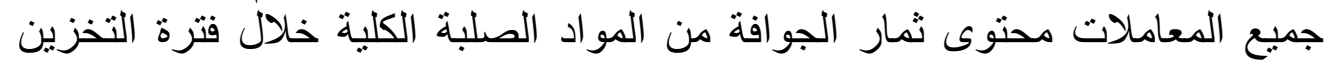
المبرد و قد احتوت المعاملة نترات كالسيوم 4 \% م أعلى متوسط فى كلا الموستون : المعين. التوصية : وينصح بالمعاملة بالثينوز الثين بتركيز 0.5 \% مع مع نتر ات الكالسيوم كغطاء



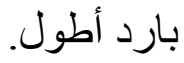

